\title{
The Transition of China's Belt and Road Initiative's High-quality Development: A Reflection of the Roles of Multiple Drivers
}

\author{
Shaocheng Jiang ${ }^{1, a}$ \\ ${ }^{I}$ College of Humanities and Law, Beijing University of Chemical Technology, Beijing, China \\ ${ }^{a}$ Email: cheng_marcello@163.com
}

\begin{abstract}
Since the second Belt and Road Forum (BRF) in April 2019, China's Belt and Road Initiative (BRI) has officially entered a phase of "high-quality development". Driven by a combination of impetus from China's leaders, domestic policy adjustments and international scepticism, the BRI has begun to gradually refine the concept of the initiative and seek a mature operational model. At the same time, the BRI itself went through being suspected, facing questions and then reinventing itself. In the post-epidemic era, the BRI's high-quality development is continuously reshaping and innovating, further influencing the world and the region.
\end{abstract}

Keywords: Belt and Road Initiative, high-quality development, cause analysis, policy analysis.

\section{INTRODUCTION}

Since 2013, China's Belt and Road Initiative (BRI) has completed its basic framework, and the BRI has built a platform for international cooperation with a significant degree of participation at the world level. As of November 2020, China has signed 201 cooperation documents with 138 countries and 31 international organizations to construct the BRI [1]. Apart from benefiting China's national interests, the BRI has gradually become an international public good with Chinese characteristics. In August 2018, President Xi Jinping proposed to "promote the transition of the joint construction of the Belt and Road Initiative towards highquality development", making the improvement of development quality an essential requirement for the next phase of the BRI's joint construction [2]. On 26 April 2019, at the Second Belt and Road International Cooperation Summit Forum, President Xi Jinping once again proposed "establishing high-quality coconstruction of the 'Belt and Road' as the mainline of future cooperation" [3]. The BRI has thus entered a new phase of high-quality construction.

As a global initiative, the BRI has already covered more than two-thirds of the world's countries. The massive investment in infrastructure projects and other cooperative programs under the initiative's high-quality development has influenced the development of regions and countries. By, for example, as of October 2020, China has signed 200 cooperation documents with 138 countries and 30 international organizations to build the "Belt and Road jointly", carried out more than 2,000 cooperation projects, and provided more than 280 shipments of emergency anti-epidemic supplies to more than 150 countries and international organizations during the epidemic [4].

With the process of high-quality development of the BRI, more and more scholars are focusing on this topic. Scholars have made innovative analyses from different perspectives. At present, the research around this topic can be broadly divided into two directions: the analysis of the theoretical connotation of the concept of highquality development and the exploration of the path of high-quality development. Chinese scholars have done most of the research.

At the theoretical level, He Yafei analysed the context and rationality of BRI's high-quality development in four aspects: innovating economic growth models, reducing world economic disparities, stimulating economic growth potential and promoting economic cooperation. $\mathrm{He}$ believes that BRI's high-quality development is of great significance to the globalisation process [5]. Zhang Chun proposed an in-depth study on the fundamental concept of cooperation in BRI, summarising new development mechanisms such as risk management, supervision and other mechanisms, as well as practical methodologies [6]. 
At the development path exploration level, Wang Kai and $\mathrm{Ni}$ Jianjun explore the goals of high-quality development of BRI and analyze the current vigorous conditions and constraints, thus suggesting new development paths in terms of infrastructure construction and regional cooperation [7]. Li Xiangyang further discusses institutionalization, focusing on improving mechanisms for investment, financing, debt management, taxation and other aspects. His research has effectively contributed to the discussion of high-quality development paths [8]. Guo and $\mathrm{Xu}$ approach the current situation and problems of BRI's new infrastructure projects. To carry out the high-quality construction of BRI, he proposes to build a technical support system, a talent training system and a financing support system [9].

Whilst the research mentioned above results and related discussions in the academic community, there is a particular gap in the research focusing on the BRI transition itself. The dynamics of the BRI shift are still not sufficiently discussed in the current literature. This article focuses on the reasons for the shift in the BRI and analyses the drivers behind the shift. It also discusses the future trends and possibilities of the BRI shift, given that it is still an evolving process.

This article draws on the Level of Analysis [10] to first review the current state of BRI development and discuss the role of leaders in the BRI transition. The paper then analyses the reasons for the BRI transition at both the national and international levels. Finally, the paper summarises these drivers and their roles and makes policy recommendations for the initiative's development.

\section{THE BRI AND THE ROLE OF CHINESE LEADERS}

In recent years, the global impact of the BRI has been significant and cannot disregard. Based on the established principles of joint construction and consensus on cooperation, between 2013 and 2018, the volume of trade in goods between China and BRI partner countries exceeded USD 6 trillion. China's direct investment in countries along the route amounted to approximately USD 90 billion. Besides, China has also exchanged cultural dimensions with more than 300 civil society organizations along the route [11]. In August 2018, Xi Jinping first proposed "high-quality development of the BRI" at the Symposium on the 5th Anniversary of Promoting the Construction of the BRI [12]. This conference revisited the BRI and established the goal of "high-quality development". The renewed development concept and actions of the BRI have progressively improved and implemented. As of July 2019, the Chinese government has signed 195 government-to-government cooperation agreements with 136 countries and 30 international organizations, extending from Asia and Europe to Africa, Latin America, the South Pacific, Western Europe and other relevant countries [11].
Moreover, the BRI's goal of "high-quality development" was repeatedly mentioned and further emphasized at the second BRF in 2019.

Chinese leaders have played an essential role in promoting the high-quality development of the BRI. Since the BRI was proposed, Chinese leaders have raised their voices to the world on building the BRI together through various channels. For example, since 2018, President Xi Jinping, Premier Li Keqiang and Foreign Minister Wang Yi have conveyed China's confidence in the BRI to the world in their speeches at various conferences and occasions. In their speeches, the "highquality development" of the BRI has emerged repeatedly to address the international community's suspicion towards the BRI. In 2019, Xi Jinping reiterated the BRI development concept at the 2nd Belt and Road Summit on International Cooperation and showed the fruits and expectations of the BRI transition. Xi responded actively to the world's concerns regarding financing cooperation, regulatory mechanisms, science and technology innovation, sustainable development, and cultural exchanges [13]. During the 2020 pandemic, Xi Jinping told the world at international conferences at different levels that China would continue to adhere to the highquality development of the BRI and make more contributions to world development [14].

In addition, Chinese Premier Li Keqiang and Foreign Minister Wang Yi have also made several statements. Their statements mirror those of President Xi Jinping in terms of concept and content and reveal more on the BRI's ongoing projects and future plan. For example, Li Keqiang has gradually made clear the formulation of high-quality construction of the BRI in his government work reports for 2019 [15] and 2020 [16]. Moreover, at the China-ASEAN Leaders' Meeting in 2020, Li Keqiang made specific references to concrete programmes and projects to deepen BRI cooperation between China and ASEAN [17]. Foreign Minister Wang Yi also advocated China's intention to build a "Healthy Silk Road", "Green Silk Road", and "Digital Silk Road" in several international forums during the pandemic period, with the aim of providing timely support to the stability of the global supply chain [18].

In general, with Xi Jinping at their core, the Chinese leaders have always looked to build the BRI together with other countries, based on the concept of "development orientation, creating momentum and sharing results" [19]. Their multiple statements reflect the importance that Chinese leaders attach to the high-quality development of the BRI and push the BRI in a positive direction. Given the changing international environment, the direction of the BRI is also becoming clear through the leaders' voices. The voices of the different leaders reflect a dual transition in the direction and level of the BRI. This transition inherits the core principles of the BRI, which are extensive consultation, joint contribution and shared 
benefits. Furthermore, it emphasizes the concrete measures, the existing systems and the expectable results of high-quality development. In the following section, the article will focus on the domestic and international factors driving the high-quality development of the BRI in this context.

\section{ANALYSIS OF INTERNAL AND EXTERNAL DRIVERS}

The drivers of a wide-ranging and far-reaching initiative are multiple. Building on the above review of the BRI's development and the leaders' role, this section focuses on more multi-faceted and concrete drivers of the BRI's transition. Faced with issues that have manifested, the BRI began to change its track. The BRI's transition proved to have both internal and external dynamics.

\subsection{Internal Considerations}

Firstly, the loss of some projects is a warning that BRI needs to make changes. After the financial crisis in 2008, China's "four trillion" massive investment programme boosted the country's economic growth. However, due to the shrinking demand in the international market, there was a dilemma of declining total international consumption rate and weak domestic demand-pull. As a result, China's surplus capacity in most basic industries increased by $20-30 \%$ [20]. Subsequently, the Chinese government launched the BRI as one of the measures to help solve these systemic problems by unlocking overseas demand for Chinese industries, construction projects and loans. In other words, the BRI helps to address these problems by stimulating external demand for Chinese goods, services and capital [21]. However, as the BRI projects unfolded, the results China expected to achieve have not been fully realized. Due to the overall lax regulation of the BRI and the inexperience of Chinese state-owned enterprises in the market, some projects suffered losses of varying degrees. For example, a US\$3.2 billion, Chinese-backed railway line in Kenya was loss-making, while the US\$4.5 billion DjiboutiAddis Ababa also encountered financial and operational difficulties [22]. In the face of such a situation, Xi Jinping proposed "Gongbi Painting" concept of BRI development, which means investing in projects with results-oriented implementation and avoiding unnecessary losses. The high-quality development of BRI requires that more projects move from losses to profits.

Secondly, China's domestic economic restructuring policy, the "New Development Concept", is also driving the BRI shift. "New Development Concept" emphasizes innovative, coordinated, green, open, and shared development. Under this new concept, the need to restructure the domestic economy has played an important role in driving the BRI transition. In 2019, Premier Li Keqiang mentioned in the government report that "downward pressure on China's domestic economy has increased, consumption growth has slowed, and effective investment growth has lacked momentum" [15]. The new economic situation has affected some Chinese provinces and enterprises' participation in the BRI and has also revealed shortcomings and weaknesses of their development. Apart from the economic problems like inadequate supply and overcapacity discussed before, China's economy's transition needs to address lack of innovation and over-consumption of resources. The initial development of the BRI has alleviated the impact of these problems, but they have not yet been fully resolved. In this phase of BRI's high-quality development, the Chinese government hopes that the shifting will provide the country with more products, technologies, and innovative ideas, thus avoiding the previous inefficient situation of pursuing quantity rather than quality [23].

In addition, Chinese leaders have proposed a "dual circulation" development pattern to test and further promote BRI transition into a high-quality development. With the global pandemic, the flow of production in countries along the BRI has been affected to varying degrees. China has had to slow down the pace of its collaborative projects with countries along the BRI. Under this situation, China expects to build a new development pattern in which both domestic and international cycles are mutually reinforcing [24]. Therefore, the concept of "dual circulation" is proposed at the meeting of the Standing Committee of the Central Political Bureau held on 14 May 2020. The main idea is that China should deepen its supply-side structural reform and give full play to the advantages of its enormous market and the potential of domestic demand. Chinese scholars consider this policy as a response to the complex external environment [25]. To respond to the evolving international situation and at the same time accelerate the release of China's domestic demand potential, the "dual circulation" development pattern and the BRI should promote each other, building China's economic corridor to connect with domestic and international markets. Faced with new environmental variables, the "dual circulation" development pattern will help BRI transition and implementation in the postepidemic era and provide Chinese enterprises with a clear direction for development. The "dual circulation" development pattern reminds Chinese enterprises of the difficulties that may arise and encourages them to improve their resilience and strengthen the BRI's achievements continuously.

\subsection{External Factors}

The above analysis of the factors internal to the BRI transition clearly shows that the Chinese government has gradually optimised the direction of the BRI in terms of agency leadership, project evaluation and execution, and domestic economic reconstruction. In this section, we 
focus on the international (mostly negative) commentary on the BRI since its launch, such as suspicion about the real intentions of the BRI, the debt trap and corruption, and then explore the role international pressure plays in the BRI transition.

Foremost, numerous voices worldwide are sceptical or even hostile about China's BRI's true intentions. The BRI is widely understood by some scholars as China's well-designed strategy to establish a new geopolitical order centred on it in Eurasia or even the world at large. The typical view is that the BRI encompasses a "well thought-out Chinese grand strategy" aimed at "recapturing geopolitical dominance in Asia and challenging the US dominance and attempting to establish a Chinese-centric order" [26]. Although China protested against this view as misleading about its intended policy as a benevolent initiative, it quickly developed a consensus in Western policy-making circles (especially in the US). The United States then-Secretary of State Rex Tillerson (2017) claimed in October 2017 that Chinese loans to finance infrastructure projects were a form of "predatory economics" designed to lead to "financing default and the conversion of debt to equity" [27].

While China intends to expand its influence in the BRI, the economic considerations far outweigh the political ones. The previous section's analysis has provided evidence that China would prefer the BRI to be more economically fulfilling. However, the doubts of Western countries, especially the US-based Western discourse, about the BRI will inevitably lead to hesitation on the partner countries' part. For this reason, since the emergence of the BRI's concept of "high-quality development", China has once again clarified the economic focus to the world and further explained its underlying philosophy.

Moreover, the "debt trap" narrative of the BRI is not infrequently found in the world media as well as in various think tanks and academic literature. In international public opinion, China is often portrayed as pursuing "debt-trap diplomacy". This narrative stems from a New Delhi think tank's view of Sri Lanka's Hambantota port in 2017 [28]. This view suggests that China is getting developing countries to agree to unsustainable loans for infrastructure projects to use them as an opportunity to expand its strategic or military influence if they run into financial difficulties. The US then Vice President Mike Pence (2018) criticized China in October 2018 for using debt-trap diplomacy in Sri Lanka to establish a "forward military base for China's growing blue-water navy" [29].

However, the fact is that a large part of the reason for Sri Lanka's debt crisis does not lie with China. Sri Lanka's Central Bank says that by $2016,61 \%$ of the government's ongoing budget deficit was financed by foreign borrowing. Between 2009 and 2016, total government debt increased by $52 \%$ to almost US $\$ 64.5$ billion. Of this, $34.2 \%$ (US $\$ 22$ billion) was external borrowing, while debt service accounted for $44 \%$ of government revenue [30]. This is compounded by the fact that BRI projects in Sri Lanka are allocated to cronies linked to the local regime [31], where the company responsible for building the Hambantota port also provided at least US\$7.6 million to assist Mahinda Rajapaksa his presidential reelection campaign in 2015 [32]. The story of the Hambantota port is the result of a political and economic disorder. The lax governance and flawed risk management shared by China and Sri Lanka made the project present a parlous picture to the outside world. Such a situation spurred China to accelerate the BRI transition, both in terms of an early release from the quagmire of the partner country itself and the need to reestablish the BRI's good international presence.

In general, it is apparent from the example above that some governments' interest in participating in the BRI may be motivated by political necessity, cupidity, or a combination of both. Western countries, led by the US, fear that the BRI will affect their established spheres of influence. Furthermore, some developing countries' ruling elites have chosen to cooperate with the BRI to varying degrees to avoid social unrest in their own countries and maintain regime legitimacy. However, the BRI was not fully prepared to face the complexities of the early period's circumstances, which contributed to the clamour for adverse voices. With the positive response of the Chinese leaders and the continuous internal adjustments, the BRI's high-quality development addresses the past flaws and begins a phase of updating.

\section{CONCLUSION}

In the analysis above, we discussed in depth the dynamics of the BRI transition and its motivations. As mentioned in the first half of the article, Chinese leaders' many statements and the positive signals sent to the international community have continued to facilitate and accelerate the transition and new layout of the BRI. While some sceptical voices in the world have provided the impetus for the BRI transition, China's difficulties in implementing projects have also contributed to the transition. The adjustment of China's national policy and new state policies have also provided an endogenous impetus for the transition. With new challenges in the world economy and the changing relationship between China and the US, the BRI transition has an externallygenerated driver for development. According to Chinese scholar Hu Biliang, the basic logic behind the operation of the kinetic system in the framework of the high-quality construction of the BRI is that the development orientation provides a new impetus for China's further development and the countries and regions concerned [19]. From China's perspective, it wants to develop bilateral markets, build cooperation projects, improve cooperation mechanisms, and strengthen cooperation 
channels with more countries to stimulate the development and upgrading of its economy and drive other countries. As a country that has benefited from the wave of globalization, China's policy of opening up to the outside world and its adherence to multilateralism principles are essential starting points for its development.

It has been three years since the high-quality development of the BRI began. In the face of the new development environment and the 2020 epidemic, the BRI development may see new adjustments. Firstly, BRI development will be more inclined to focus its limited resources on critical regions and industries. The discourse is beginning to show a trend of emphasizing regional cooperation and quality. According to statistics from the Ministry of Commerce of the People's Republic of China, Chinese enterprises invested US\$15.04 billion in nonfinancial direct investment in 56 countries along the Belt and Road in 2019, down 3.8\% year-on-year and accounting for $13.6 \%$ of the total for the same period. The funds are mainly invested in Singapore, Vietnam, Laos, Indonesia, Pakistan, Thailand, Malaysia, the United Arab Emirates, Cambodia and Kazakhstan [33]. With the epidemic well under control in Asia and the signing of the Regional Comprehensive Economic Partnership Agreement (RCEP), it is reasonable to infer that the development centres after the BRI will focus on the Asian region. Secondly, according to the Economist Corporate Network's analysis, China's economic relations with the ASEAN markets will continue to deepen, with Vietnam, Singapore and Malaysia as China's main trading partners in the BRI [34]. From 31 March to 3 April 2021, Wang Yi hosted five Southeast Asian Foreign Ministers (Singapore, Malaysia, Indonesia, the Philippines and South Korea) to visit China. During the press conference, Chinese Foreign Minister Wang Yi again referred to the BRI high-quality development when answering a reporter's question on the 30th Anniversary of ASEANChina Dialogue Relations. He expected to "promote the entry into force of the Regional Comprehensive Economic Partnership Agreement (RCEP) as soon as possible, to turn East Asia into a new engine to drive the global post-epidemic economic recovery" [35]. This statement reflects China's confidence in its continued commitment to East Asia and the positive role of the BRI in restoring the East Asian economy to a sustainable state.

Besides, the investment targets and industrial structure of the BRI will also be adjusted. As Wang Yi mentioned, "we will continue to work with other countries to build 'fast corridors' for people's movement and 'green corridors' for the transportation of goods" [36]. The BRI will give a higher weight in developing manufacturing and service sectors such as health care in the period to follow. On the one hand, it will adapt to the need to prevent and control epidemics, and on the other hand, it will optimize a reasonable investment structure. Finally, the overall layout of the BRI is likely to take on a more stable and cautious appearance. Under the blow of the epidemic, the world economy is under more significant pressure to develop, and many countries are under pressure to develop their economies. The construction and investment of the BRI will likely be more alert to debt risks and investment security, striving for each project's actual economic benefits.

In addition, China's leadership of the BRI is refined and strengthened, as evidenced by the recent realignment of key Chinese officials in their positions. On 8 April 2021, according to the Chinese Ministry of Human Resources and Social Security, the State Council appointed Luo Zhaohui as Director of the China International Development Cooperation Agency [37]. The agency is responsible for formulating strategic guidelines, plans and policies for foreign aid, coordinating and making recommendations on major foreign aid issues [38]. The department was once officially positioned as a function to "better serve the overall layout of national diplomacy and build BRI" [39]. Since its establishment on 18 April 2018, the agency has been under the joint responsibility of the Ministry of Commerce, the Ministry of Foreign Affairs and the Ministry of Finance. Luo has the solid diplomatic experience, particularly during his tenure as Chinese Vice Foreign Minister, focusing on the Asian region, treaty law, border and maritime affairs and consular work [40]. This change again reflects the possible focus of the BRI around Asia. Based on the change and Wang Yi's voice, this paper deduces that this not only reflects China's awareness of the loose state of its past leadership of the BRI institutions, and it is beginning to make changes. Meanwhile, it also reflects the fact that China's Ministry of Foreign Affairs is no longer in an awkward position in developing the BRI. With the apparent assertiveness of China's foreign policy and stance, the Ministry of Foreign Affairs will also play a more critical role in the future development of the BRI.

Overall, China's Belt and Road Initiative has undergone a conceptual reshaping, rule optimization and restructuring since the second Belt and Road Forum in April 2019. The Forum and the leaders' speeches were widely seen as reflections of China's desire to renew and reawaken the initiative, demonstrating its willingness to build more inclusiveness, transparency and sustainability into the projects involved. While the world is currently facing new challenges from the impact of the epidemic, the international community is in a state of flux. Nevertheless, the targeted action, improved governance and more stakeholder-approved solutions that China is currently demonstrating mean that the Belt and Road Initiative is moving towards a new, more mature stage.

\section{REFERENCES}

[1] Belt and Road Database. (2020). "China has signed 201 cooperation documents with 138 countries and 31 international organizations to build the Belt and 
Road". https://www.ydylcn.com/zx/336655.shtml

[2] Chinese Government Website. (2018). Xi Jinping attended and delivered an important speech on the 5th Anniversary of Promoting Belt and Road Construction.http:/www.gov.cn/xinwen/201808/27/content_5316913.htm.

[3] Belt and Road Forum Website. (2019). Xi Jinping's Opening Speech at the Round Table Summit of the 2nd Belt and Road Forum for International Cooperation.http://www.beltandroadforum.org/n10 0/2019/0427/c24-1307.html.

[4] Xinhua Net. (2020). More than 2,000 cooperation projects: Belt and Road is a detailed "Gongbi painting".http://www.xinhuanet.com/fortune/202010/10/c_1126588587.htm

[5] He Y. F. (2019). How to Promote the High-Quality Development of Belt and Road. Global Times, 014.

[6] Zhang C. (2020). Toward A High-Quality Development Theory for the Belt and Road Initiative. Global Review(04), 111-131+153-154.

[7] Wang K., Ni J. J. (2019). The High - quality Construction of the Belt and Road Initiative. Contemporary International Relations(10), 28$34+59$.

[8] Li X. Y. (2020). High-Quality Development and Institutionalization of the BRI. World Economics and Politics(05), 51-70+157.

[9] Guo C. X., Xu F. (2020). Research on New Infrastructure Promoting High-Quality Development of the "Belt and Road" Construction. Journal of Xi'an Jiaotong University(Social Sciences)(05), 1-10.

[10] Waltz, K. N. (1959). Man, the state, and war: A theoretical analysis. New York: Columbia University Press. Chicago (Author-Date, 15th ed.).

[11] Belt and Road Portal. (2019). A six-year report on the Belt and Road Initiative. https://www.yidaiyilu.gov.cn/xwzx/gnxw/102792.h tm

[12] Chinese Government Website. (2018). Xi Jinping attended a symposium on the 5th anniversary of promoting the construction of "One Belt, One Road" and delivered an important speech. http://www.gov.cn/xinwen/201808/27/content_5316913.htm

[13] Chinese Government Website. (2019). Xi Jinping's keynote speech at the opening ceremony of the 2nd Belt and Road Forum for International Cooperation. http://www.gov.cn/xinwen/2019. 04/26/content_5386544.htm
[14] Chinese Government Website. (2020). Xi Jinping's speech at the 27th informal meeting of APEC leaders.http://www.gov.cn/xinwen/202011/20/content_5563097.htm

[15] Chinese Government Website. (2019). Report on the Work of the Government Premier. http://www.gov.cn/premier/201903/16/content_5374314.htm

[16] Chinese Government Website. (2020). Report on the Work of the Government_Premier. http://www.gov.cn/premier/202005/29/content_5516072.htm

[17] Ministry of Foreign Affairs of the People's Republic of China. (2020). Speech by Li Keqiang at the 23rd China-ASEAN Leaders' Meeting Premier. http://www.gov.cn/premier/202011/12/content_5560934.htm

[18] Ministry of Foreign Affairs of the People's Republic of China. (2020). "Strengthening Solidarity and Cooperation for a Better Future" - Video Message by State Councilor and Foreign Minister Wang Yi at the Global Think Tank Conference on "Rebuilding the World after the Epidemic". https://www.fmprc.gov.cn/web/wjbzhd/t1834011.sh tml

[19] Hu B. L. (2020). Promoting high-quality development of Belt and Road Initiative - Xi Jinping's systematic discussion on high-quality construction of Belt and Road Initiative. Study \& Exploration(10), 102-119+2+192.

[20] European Union Chamber of Commerce in China. (2016). Overcapacity in China: An Impediment to the Party's Reform Agenda, Beijing: European Chamber of Commerce. https://www.europeanchamber.com.cn/en/publicati ons-archive/405/Overcapacity_in_China An_Impediment_to_the_Party_s_Reform_Agenda

[21] Chen Y. J., Deng Z. Q., Zhang J. H. (2019). An economic analysis of the "Belt and Road" initiative to achieve win-win cooperation is based on benefit creation and sharing mechanism. Journal of Xiamen University (Arts \& Social Sciences Edition) (05),8397.

[22] Pilling, D., Feng, E. (2018), 'Chinese investments in Africa go off the rails', Financial Times. https://www.ft.com/content/82e77d8a-e716-11e88a85-04b8afea6ea3

[23] Hu J. H. (2017). The "Belt and Road" strategy and the new development concept fit together. Study Times,003.

[24] People's Daily. (2020). Meeting of the Standing 
Committee of the Central Political Bureau held. http://paper.people.com.cn/rmrb/html/202005/15/nbs.D110000renmrb_01.htm

[25] Zhao Y. C. (2020). New trends in economic globalization and the construction of a "dual circulation" development pattern after the epidemic. The Journal of Humanities (11),65-71.

[26] Bhattacharya, A. (2016). 'Conceptualizing the Silk Road Initiative in China's Periphery Policy', East Asia, 33(4), pp. 309-28.

[27] Tillerson, R. (2017). 'Defining Our Relationship with India for the Next Century: An Address by US Secretary of State Rex Tillerson'. https://www.csis.org/analysis/defining-ourrelationship-india-next-century-address-ussecretary-state-rex-tillerson

[28] Challancy, B. (2017). Sri Lanka the latest victim of China's debt-trap diplomacy. https:/asiatimes.com/author/brahma-chellaney/

[29] Pence, M. (2018). Remarks by Vice President Pence on the Administration's Policy Toward China. https://www.whitehouse.gov/briefingsstatements/remarks-vice-president-penceadministrations-policy-toward-china

[30] Central Bank of Sri Lanka. (2016). Public Debt Management in Sri Lanka: Performance in 2016 and Strategies for 2017 and Beyond, Colombo: Public Debt Department. http://financedocbox.com/Mutual_Funds/12275226 6-Public-debt-managementin-sri-lanka.html

[31] Kelegama, S. (2017). 'The Political Economy of the Rajapaksa Decade in Sri Lanka, 2005-14: Policy Contradictions and Mal-governance', in Hill, H. and Menon, J. (eds), Managing Globalization in the Asian Century: Essays in Honour of Prema-Chandra Athukorala, Singapore: ISEAS - Yusof Ishak Institute, pp. 428-56.

[32] Abi-Habib, M. (2018). 'How China Got Sri Lanka to Cough Up a Port', New York Times, 7 Aug. 2018. https://www.nytimes.com/2018/06/25/world/asia/c hina-sri-lanka-port.html

[33] Ministry of Commerce of the People's Republic of China. (2019). China's Investment Cooperation with Countries Along the Belt and Road in 2019. http://www.mofcom.gov.cn/article/tongjiziliao/dgzz /202001/20200102932445.shtml

[34] Baker McKenzie. (2019). The Economist Corporate Network: BRI BEYOND 2020 Embracing new routes and opportunities along the Belt and Road. https://www.bakermckenzie.com/en/insight/publica tions/2019/11/bri-beyond-2020
[35] Ministry of Foreign Affairs of the People's Republic of China. (2021). 'State Councillor and Foreign Minister Wang Yi receive five foreign ministers from neighboring countries in an interview with the media after their visit to China'. https://www.fmprc.gov.cn/web/wjbzhd/t1866842.s html

[36] Ministry of Foreign Affairs of the People's Republic of China. (2021). Strengthening unity and cooperation and preventing confrontation and division is the only correct choice for the international community. https://www.fmprc.gov.cn/web/wjbzhd/t1819523.s html

[37] Ministry of Human Resources and Social Security of the People's Republic of China. (2021). China's State Council Appoints and Removes State Staff. http://www.mohrss.gov.cn/rss/gwyrm/202104/t202 10408_412387.html

[38] The China International Development Cooperation Agency Website. (2021). China International Development Cooperation Agency's main functions. http://www.cidca.gov.cn/zyzz.htm

[39] Wang Y. (2021). Note on the State Council's Institutional Reform Program. http://www.gov.cn/guowuyuan/201803/14/content_5273856.htm

[40] The China International Development Cooperation Agency Website. (2021). Biography of Luo Zhaohui.http://www.cidca.gov.cn/202104/08/c 1211102147.htm 